\title{
Understanding the Gender Gap Further: The Case of Turn-of-the-Century Swedish Compositors
}

\author{
Joyce Burnette and Maria Stanfors
}

To better understand the historical gender wage gap, we investigate the wages of Swedish compositors circa 1900 using a rich data set of matched employeremployee information with national coverage. In line with previous findings, women earned about 70 percent of men's wages on average. Individual and job characteristics explain much of this shortfall. Firm characteristics or firm fixed effects, on average, explain 17 percent of the gap, though the firm mattered more for the gender gap in big cities than elsewhere. Sorting across firms is thus an important part of understanding historical gender wage gaps. While most studies conclude that a significant portion of the gender gap is unexplained, suggesting labor market discrimination, this may result from a lack of information on the distribution of men and women across firms.

$\mathrm{D}$ espite women's advances in the economy and society over time, women still earn substantially less than their male counterparts in the labor market. The fact that men and women are not, and rarely have been, paid the same wages makes understanding the gender wage gap an important mission for economists and economic historians. One way to further our understanding of this persistent inequality is to collect and analyze new data that allow us to better connect the inequities of the past to those of the present.

During the nineteenth century, gender wage gaps in the United States and Europe were large (around 30-50 percent), with sorting across jobs and men's greater physical strength explaining a large portion of the difference (Burnette 2008, 2015). While industrialization in some cases increased the demand for human strength (Samuel 1992), eventually machine power substituted for brawn. The coincident rise of

The Journal of Economic History, Vol. 80, No. 1 (March 2020). (C) The Economic History Association. doi: 10.1017/S002205071900086X. This is an Open Access article, distributed under the terms of the Creative Commons Attribution license (http://creativecommons.org/ licenses/by/4.0/), which permits unrestricted re-use, distribution, and reproduction in any medium, provided the original work is properly cited.

Maria Stanfors is Professor, Department of Economic History, Lund University, P.O. Box 7083, 22007 Lund, Sweden. E-mail: maria.stanfors@ekh.lu.se (corresponding author). Joyce Burnette is Professor Department of Economics, Wabash College, Crawfordsville, IN 47933. E-mail: burnettj@wabash.edu.

The authors acknowledge financial support from the Institute for Evaluation of Labour Market and Education Policy (IFAU) [Dnr 2012/144] and the Swedish Research Council (VR) [Dnr 421-2013-671]. The authors thank editor William Collins and two anonymous reviewers for extremely good guidance and insightful comments. A previous version of this paper was presented at the World Economic History Conference in Cambridge, MA. Comments and suggestions from seminar participants are gratefully acknowledged. 
services demanded qualitatively different skills that were more equally distributed among men and women or favored women, but gender wage differences did not disappear (Goldin 1990). In the United States and Europe, the gender wage gap declined as men's and women's human capital converged during the late twentieth century, but nevertheless it has persisted, especially in top jobs, and continues to be studied by many (Goldin 2014; Bertrand 2018).

Discrimination has long been cited as a potentially important explanation for the gender wage gap, both for theoretical reasons and for reasons of convenience, as it provides an interpretation for the residual part of the gender gap (i.e., the portion of the gap that cannot (yet) be accounted for given the information at hand). This is understandable because the first reaction to the observation that women earn less than men for similar work is often that this may reflect differential treatment in the marketplace. For example, in 1797, Frederick Eden was puzzled by the wage gap he observed among English farm servants: "The wages of men-servants $\ldots$ are from 9 to 12 guineas a year; whilst women ... with difficulty get half as much. It is not easy to account for so striking an inequality, and still less easy to justify it" (Eden 1797, vol. ii, p. 47).

Although Eden could not understand the gender wage gap he observed, subsequent research has explored the gap at various times and places. For example, around the turn of the twentieth century, contemporary observers, such as Edith Abbott and Sophonisba Breckinridge (from the United States) and William Edgeworth and Sidney Webb (from the United Kingdom), engaged with the issue of women earning less than men in industry (and elsewhere) in a more insightful way than Eden. In books and articles, they listed factors that potentially explained the gender gap in wages, including women's relative youth and inexperience as well as their lack of physical strength and education, low skills, and career interruptions (Webb 1891; Edgeworth 1904; Abbott and Breckinridge 1906; Abbott 1910). They also discussed women's concentration in certain industries and jobs, lack of unionization, and outright sex discrimination on behalf of employers and co-workers. Hence, contemporary observers were quite well aware of the role of individual (human capital) characteristics and job characteristics together with institutional and social factors for women's lower wages, but could not properly test their conjectures.

Later, modern research has been able to account for much of the gender wage inequality observed in the nineteenth century. Productivity estimates suggest that women were less productive than men in both agriculture and manufacturing (Cox and Nye 1989; Burnette 2015). While many studies of the contemporary labor market have attributed part of the 
gender gap to differences in individual characteristics (for a review, see Altonji and Blank 1999), individual-level data are scarcer for the nineteenth century. Where such data are available, much of the gender wage gap can be explained by individual characteristics. McHugh (1988, p. 34) finds that experience alone explains 40 percent of the gender wage gap among workers in a southern U.S. cotton mill from 1880 to 1915. Using a broader range of individual characteristics, including firm tenure and marital status, Goldin (1990, p. 102) explains about two-thirds of the gender wage gap among nineteenth-century manufacturing workers in California. While some (early) researchers attribute the unexplained (residual) part to discrimination, it is now well understood that the residual must always be interpreted with caution because it likely captures omitted variables as well (i.e., unobserved characteristics that affect pay and are correlated with gender). Thus, improvements in data quality, particularly when it comes to variables that are highly relevant and accurate measures of characteristics affecting productivity and pay, tend to erode the residual wage gap and improve our understanding of the gender gap.

Against this backdrop, the present study investigates the gender wage gap among compositors working in the Swedish printing industry around the turn of the last century (circa 1900). Typesetting was a gender-mixed occupation, despite being a highly skilled manufacturing trade and male dominated. The job did not require much physical strength, but demanded, for the time, considerable smarts and stamina. The union accepted both men and women. We have access to unusually rich employer-employee matched data with national coverage. Looking within firms allows us to compare men and women who do the same job at the same place and at the same time. Such data are rare historically, but they are valuable for understanding gender wage gaps because they permit such close comparisons of workers.

We expect that it will be useful to incorporate information on firms given their salience for wage setting. ${ }^{1}$ Nevertheless and unfortunately, the firm and firm characteristics are largely neglected in historical studies of wages and the gender gap, primarily due to the lack of data and relative rarity of gender-mixed occupations within firms. There are many reasons why the firm should matter for wages. A positive association between firm size and workers' wages, first discovered by Moore (1911), is well

\footnotetext{
${ }^{1}$ Recent research (Card, Cardoso, and Kline 2016; Sorkin 2017) shows that firm characteristics explain a sizeable part of the gender wage gap. Sorting across firms explains about 15 percent of the gender wage gap in present-day Portugal and 25 percent of the gender gap in present-day United States (though part of the larger sorting component found for the United States may be due to lack of information on hours).
} 
documented for modern contexts (Mellow 1982; Brown and Medoff 1989; Oi and Idson 1999), indicating that small and large firms differ with respect to training, productivity, and wage structure. The size-wage premium is attributed partly to efficient matching of productive workers and employers, and partly to managerial practices in that large employers pay efficiency wages to deter shirking or adopt a discretionary wage setting to share rents (Slichter 1950; Oi and Idson 1999).

We ask how large the gender wage gap was in this historical setting and examine to what extent worker and firm characteristics (including size) account for it by means of wage decompositions. We find that the raw gender wage gap for compositors was large, around 30 percent. This overall gap is mainly explained by individual characteristics that differed between men and women, but, importantly, we find that additionally accounting for firm characteristics nearly eliminates the gender wage gap among compositors. Firm characteristics account for 17 percent of the gender wage gap, which is in line with what Card, Cardoso, and Kline (2016) find for present-day Portugal. ${ }^{2}$

The results show that sorting across firms is an important part of understanding historical gender wage gaps and highlight the importance of male-to-female differences in distributions across firms in wage inequality in the past, which has been neglected in previous research. Because we examine the labor market for a particular occupation, at a particular point in time, we do not pretend our results are generalizable to all jobs in all contexts in the past. Moreover, even though we are able to account for the entire gender wage gap among compositors, the results do not imply that the wage difference between men and women was entirely "fair" or that the market itself was free from discrimination. Women's "pre-market" individual characteristics may have been the result of discriminatory treatment, hiring across firms might not have been gender-neutral, and women might not have found it as easy as men to enter this skilled occupation, which was considered "labor aristocracy" around 1900. Thus, gender discrimination in various forms may have existed and mattered at other stages than what we analyze.

\section{THE GENDER WAGE GAP AND WAGE DISCRIMINATION}

The gender wage gap is typically explained as a product of market forces or customary practices such as discrimination. Market-based explanations see gender differentials as reflecting productivity differentials,

\footnotetext{
${ }^{2}$ We are, like Card, Cardoso, and Kline (2016), able to account for hours in the analysis.
} 
related to qualifications, such as skill, or experience (Becker 1964; Mincer 1974), while another strand of literature ascribes the gender gap to discrimination. It is a challenge to discern between the two broad explanations. Empirically, a common approach has been to decompose the gender wage gap into a portion that is attributable to differences in observable productive characteristics and an "unexplained" portion that may be a proxy for wage discrimination. ${ }^{3}$

\section{Wage Discrimination}

Wage discrimination is sometimes defined as the unexplained wage gap. Goldin (2014, p. 1093) notes that "The 'residual' is often termed 'wage discrimination' since it is the difference in earnings between observationally identical males and females." Altonji and Blank (1999, p. 3156) argue that this terminology can be misleading since the unexplained gap "captures both the effects of discrimination and unobserved group differences in productivity and tastes." The fact that controlling for more variables systematically decreases the portion of the wage gap that is unexplained should lead us to be skeptical of the value of defining wage discrimination this way.

For the purposes of this study, we prefer to define wage discrimination as any difference in men's and women's wages not justified by differences in productivity, given that they do the same job. This definition makes wage discrimination equivalent to Becker's market discrimination coefficient, which he defined as the difference between the observed wage ratio and what the ratio would have been without discrimination (Becker 1971, p. 17). Becker pointed out that discrimination, on average, does not necessarily mean discrimination at the margin. If there are enough non-discriminating employers, then discrimination is competed away, and those employers will have higher profits. This implies that women do not work for discriminating employers, which leads to sorting across firms but not to differences in pay. If, however, there is a large enough share of prejudiced employers, then prejudice at the margin will create a wage gap. ${ }^{4}$

The history of wage discrimination remains an active area of research that contributes to our understanding of the historical gender wage gap.

\footnotetext{
${ }^{3}$ For excellent reviews of the modern gender wage gap literature, see Altonji and Blank (1999) and Kunze (2018).

${ }^{4}$ Similarly, as prejudiced co-workers demand a premium to work alongside women, segregation occurs, and as customers discriminate against women, the labor market return will decrease for women in jobs with customer contact.
} 
Generally, wage discrimination was less common during the nineteenth century and more common during the twentieth century. In the United States, Goldin (1990) finds that the unexplained portion of the wage gap was only 20 percent for manufacturing during the late nineteenth century, but was 55 percent for clerical workers in 1940. For nineteenth-century manufacturing, Burnette (2015) finds no evidence of wage discrimination in the United States and Cox and Nye (1989) find no evidence of wage discrimination in France. Stanfors et al. (2014) fully explain the withinfirm wage gap for piece-rate cigar makers (using a mold) in Sweden circa 1900. Twentieth-century studies, some using matched firm-worker data, find indications of wage discrimination in the United States (Leonard 1984; Hellerstein, Neumark, and Troske 1999), but not in Norway, Israel, or Sweden (Haegeland and Klette 1999; Hellerstein and Neumark 1999; Meyersson Milgrom, Petersen, and Snartland 2001). Since the nineteenthcentury studies largely focused on lower-skilled manufacturing workers, there remains a need for studies of skilled workers of the era.

Competitive markets for homogenous goods limited firms' ability to discriminate in ways that raised unit labor costs. One reason for change over time may be that more people worked on piece rates during the nineteenth century when spot labor markets were common, work was simple, and individual productivity was easily measured. When working on piece rates, men and women were generally paid the same rate, implying no wage discrimination (Goldin 1990; Burnette 2008; Stanfors et al. 2014), while time-rate wages implied more discretion in wage setting on behalf of the employer. There also seems to be a difference between skilled and unskilled workers. In U.S. manufacturing in 1900, female clerical workers experienced wage discrimination, but female production workers did not (Burnette 2015). As we write the history of wage discrimination, then, it seems important to examine skilled industrial workers on time-rate wages because they are not yet part of the narrative and may provide us with important insights. Will their wages look more like those of unskilled piece-rate workers or more like clerical workers? In order to find out, we examine Swedish compositors, a group of skilled bluecollar workers who worked primarily on time rates, ${ }^{5}$ at the dawn of the twentieth century. Because this occupation was high skilled, we might expect to find more discrimination there than in a low-skilled occupation

\footnotetext{
${ }^{5}$ In 1902/03, the overwhelming majority of compositors were paid time-rate wages only (72.6 percent of male compositors working by hand and 82.1 percent of those working by machine were paid time-rate wages only, the equivalent among women being even higher). Other compositors were partly paid piece rates, though the share of pay was typically small and varied according to location and enterprise.
} 
(compare Bertrand 2018), and because it did not require strength, and was more of a level playing field, we do not need to consider gender differences in strength in our analysis. The fact that we have access to matched employer-employee data and information on the firm where the compositors worked allows us to investigate whether the gender wage gap can be explained by different standards among employers when it comes to the treatment of men and women within the same firm (compare Lazear and Rosen 1990).

\section{Firms and Wages}

Economists have shown that wages vary across firms, even after controlling for worker heterogeneity (e.g., Abowd, Kramarz, and Margolis 1999). For example, controlling for individual characteristics, establishment explained one-fifth of wage variation in Germany during the period 2002/09 (Card, Heining, and Kline 2013). Studies have shown that wages vary with measured characteristics such as firm size and percent of the workforce that is female. Contemporary studies typically find that larger firms pay higher wages. Brown and Medoff (1989) conclude that the impact of firm size is not entirely due to sorting by worker quality; even controlling for individual fixed effects, there is a positive correlation between firm size and wages. Firm size is also positively correlated with the gender wage ratio. Heinze and Wolf (2010) find that the gender wage gap decreases with firm size, but increases with firm market power. There is no general agreement on why wages increase with firm size. Larger firms may pay efficiency wages to manage monitoring problems. Larger firms may also have greater incentives to discourage unionization and pay higher wages to discourage unions (Brown and Medoff 1989). Worker productivity may be higher at larger firms, which can use workers more efficiently and thus are able to share rents (Oi and Idson 1999).

Individuals, however, earn less when they work at plants with more female workers. Slichter (1950) noted a negative correlation between the earnings of unskilled male workers and the share of workers who were women. Studies that are more recent document that both men and women earn lower wages in firms with a high percentage of women, and that this penalty is greater for women than for men (Carrington and Troske 1998; Chevalier 2007). Co-worker discrimination would imply that firms hiring women would have to pay men higher wages to compensate for the disutility of having female co-workers, which is not consistent with the fact that men earn less at firms hiring more women. On the other hand, employers with a taste for discrimination might be willing to hire more 
women if they can pay them less. Ostroff and Atwater (2003) suggest that those who work primarily with women are considered less valuable and thus earn less.

Some differences in earnings across firms may simply be compensating differentials for firm location, in that big city firms have to pay more because the cost of living is higher, and in order to compensate for urban disamenities.

Firms may also differ in ways that are harder to measure. There are intangible aspects of work organization and management that may be important for wages, particularly with respect to gender. The historical literature finds that firms often offered men and women different contracts. Men were offered jobs with delayed compensation, while women were not. Goldin (1986) suggests that firms chose different incentive structures for men and women based on their expected careers. Based on their shorter expected careers, women segregated into jobs with short learning periods, while men, who had longer expected tenures, sorted into jobs where they were incentivized with on-the-job training and delayed compensation. In typesetting, which was skilled manufacturing work, there was room for learning on the job. We expect to find that men were at an advantage compared to women when it comes to on-the-job training, which, all else equal, affected their earnings positively.

\section{HISTORICAL CONTEXT}

Our study is situated in Sweden in 1902/03. By 1900, manufacturing employed 20 percent of the total labor force. Among working-age women, 19 percent (most of them young and single) were employed in the formal economy, primarily in domestic service and textile production, which paid considerably less than gender-mixed jobs such as cigar making and typesetting. The printing industry included many fields and trades. We focus on compositors, as theirs was the most common and the key occupation within the industry. Compositors engaged in typesetting, which was neither a typical manufacturing job nor a white-collar job; it was a skilled blue-collar job. Compositors earned more than the average male wage in manufacturing, ${ }^{6}$ and were, in Sweden and elsewhere, among the first to form trade unions (Wessel 1937; Schmick 2018). The turn of the twentieth century was a time of technological change in the printing

\footnotetext{
${ }^{6}$ In 1902, around 80 percent of the male (adult) compositors earned more than 1,200 krona per year, which gave them the right to vote in the elections to the lower chamber of the parliament. Swedish women did not gain suffrage until 1921.
} 
TABLE 1

OCCUPATIONAL SORTING IN THE SWEDISH PRINTING INDUSTRY 1902/03

\begin{tabular}{lcccccc}
\hline \hline & $\begin{array}{c}\text { Number of } \\
\text { Workers }\end{array}$ & $\begin{array}{c}\text { Share Women } \\
(\%)\end{array}$ & $\begin{array}{c}\text { Apprentices } \\
(\%)\end{array}$ & $\begin{array}{c}\text { Average } \\
\text { Wage } \\
(\text { Men })\end{array}$ & $\begin{array}{c}\text { Average } \\
\text { Wage } \\
\text { (Women) }\end{array}$ & $\begin{array}{c}\text { Female-to- } \\
\text { Male Wage } \\
\text { Ratio }\end{array}$ \\
\hline Supervision & 98 & 3 & 0 & 58 & 57 & 0.99 \\
Typesetting & 2,861 & 13 & 25 & 38 & 26 & 0.70 \\
"Snällpress" & 1,571 & 17 & 32 & 27 & 17 & 0.63 \\
Stereotyping & 310 & 10 & 25 & 36 & 23 & 0.62 \\
Lithography & 545 & 7 & 36 & 31 & 27 & 0.87 \\
Bookbinding & 1,914 & 64 & 16 & 30 & 16 & 0.52 \\
Miscellaneous & 498 & 7 & 4 & 17 & 20 & 1.21 \\
All printing & 7,797 & 25 & 23 & 33 & 18 & 0.57 \\
\hline
\end{tabular}

Notes: This table excludes observations with missing values for a field. Figures subject to rounding. "Snällpress" is Swedish for a cylinder press, which was used for printing books.

Source: Undersökning av tryckerier mm 1903, Avdelningen för arbetsstatistik, HII a:1 vol 1-6 samt HII a:2 vol 1-12, Kommerskollegiets arkiv, National Archives (Riksarkivet), Stockholm.

industry, affecting typesetting in particular. The linotype machine was new, and some of the firms in our study adopted new machines, while most of the work in the industry continued on the traditional letterpress. As mentioned above, typesetting in Sweden was gender-mixed but maledominated. There were no rules preventing female employment or union membership, though the compositors' union was strong and known to be male-biased (Karlsson and Stanfors 2018). Women were less likely to operate a machine and more likely to work by hand. Nevertheless, men and women with similar skills worked side by side within factories (Elmquist 1909).

There was occupational sorting by gender in the printing industry. Table 1 shows employment and wages by gender, as reported in the industry-wide survey that we describe in more detail in the next section. Most women worked in bookbinding, which paid a lower-than-average wage. For the industry as a whole, the gender wage ratio was 0.57 , but in typesetting, it was 0.70 . We do not attempt to explain gender wage gaps for the entire industry, which would be a story about occupational sorting and segregation, but only for compositors. For the reasons stated above, we focus on a skilled occupation, which included women and with no obvious reason for them to earn less. In a way, typesetting was ideal for women, since it relied more on brain power than strength. ${ }^{7}$

\footnotetext{
7 The fact that compositors were skilled and earned more than other workers implies that workers, irrespective of gender, were positively selected.
} 
Typesetting is the composition of text by means of types. During the letterpress era, moveable type was composed by hand for each page. Cast metal sorts were composited into words and lines of text and bound together to make up a page image, forme, with all letter faces exactly the same height to form an even surface of type. This was mounted in a press, inked, and pressed on paper. Typesetting by hand was complemented by continuous casting or hot-metal typesetting machines, such as the linotype, at the end of the nineteenth century. Machines enabled one operator to do the work of ten hand compositors by automating the selection, use, and replacement of sorts, with a keyboard as input. This revolutionized typesetting and printing-before, no newspaper had more than eight pages. Typesetting was, at the time of the survey, skilled work with some compositors working by hand and some by machines, which was considered more challenging. In our data, most of the compositors worked by hand.

Typesetting required some formal skills, as workers had to have above-average literacy and even be proficient at mirror-image reading. Typesetting as a trade was growing, with formal apprenticeship providing for training of younger workers entering the trade. According to Elmquist (1909), there were, at the time of the survey, 40-45 apprentices for every 100 skilled compositors in the entire industry, though after we limit the data set, the share of apprentices is smaller; 13 percent of the compositors were women, which was less than the 25-percent industry average.

The Typographers' Union was founded in 1886. Around the turn of the century, it had 58 locals and almost 3,000 members. In 1907, the union density of Swedish compositors was estimated at 86 percent, which was high compared to other occupations and also compared to compositors in other countries (Friedman 2008). Unionization took place against the background of technological change; an important objective of the Typographers' Union was to regulate the use of new technology while protecting the skills of union members (e.g., through apprenticeship). Despite a tough attitude toward female compositors, indicating male bias, the union had an inclusive strategy with the goal to maximize membership in order to increase wages, and the original statutes of the Typographers' Union explicitly mentioned that members could be of either sex. ${ }^{8}$ The gender gap in union membership was mainly a result of

\footnotetext{
${ }^{8}$ Predecessors of this national union did not allow women to join in an attempt to keep women out of the trade to avoid competition for work and wage underbidding. The more inclusive strategy of the Typographers' Union instead emphasized equal pay for equal work.
} 
women being younger and less experienced; adjusting for individual and firm characteristics makes this gap insignificant (Karlsson and Stanfors 2018).

In the United States, the National Typographic Union opposed women's employment (Kessler-Harris 1982, p. 70), but the 1900 census reports that 26 percent of compositors were women (Census Bureau 1904, Table 1). In the United Kingdom, London had strong unions; fewer women worked in the industry, and women were only admitted to the union if they "earned the Trade Union rate," which meant that few women were union members (Webb 1891). The Edinburgh union was weaker, and more women worked as compositors there (Bradby and Black 1899). In the United Kingdom, female compositors earned less than men, and there was some disagreement among contemporaries about why. Webb (1891) claimed that the women were paid lower piece rates, while Edgeworth (1904) concluded that women and men did different work. Bradby and Black (1899, p. 265) noted that women not only earned less, but also received less training, indicating that wage gaps among British compositors probably were related to training differences more than to any other female disadvantages:

The boy is apprenticed for seven years, during which time he learns all branches of the trade ... For the girls there is no regular system of apprenticeship, and the length of their training varies. Usually it lasts for three or four years, ... This practice is said to suit them better, since, as it is probable that they will marry and leave off work, they hardly care to spend seven years out of their wage-earning life in being trained.

Though the work and wages of compositors differed across settings, this contemporary description of training is consistent with what we observe for Swedish compositors. Both sexes were apprenticed, but women seem to have had shorter apprenticeships. At the time of the survey, a greater percentage of the female workforce was apprenticed (33 percent of women and 23 percent of men). However, this results from the fact that women in typesetting had less experience. If we divide the workforce into experience groups, each group contains a smaller share of female apprentices. Among compositors with up to five years of experience, 73 percent of women and 83 percent of men were apprentices. Among compositors with six to ten years of experience, 7 percent of women and 10 percent of men were apprentices. Thus, women were more likely to be apprentices at the time of the survey because of their lower levels of experience. 
Our data serve our research purpose well. They come from a survey of the printing industry in 1902/03, conducted by the Swedish Board of Commerce (Kommerskollegium). ${ }^{9}$ The entire industry was surveyed with one set of questions for employers and another for employees.

The data set is unique in many ways ${ }^{10}$; we know not only a wide variety of workers' characteristics, but also the firm at which each person worked. Because workers reported both weekly earnings and hours worked, we are able to use hourly wages as our dependent variable. ${ }^{11}$ This is particularly useful in gender analysis, since the danger of using weekly earnings is that women may have been paid less because they worked shorter hours. Earnings refer to cash earnings and do not include the value of fringe benefits; we adjust for differences in earnings arising from benefits by including a variable indicating whether the worker received free housing. We also control for whether the individual worked night shifts or Sundays, which may have affected earnings.

Data contain direct measures of experience in the trade, which is unusual. Labor economists often follow Mincer (1974), who defined experience as the number of years since leaving school. In the context we study, it would be misleading to assume that a worker's education was equal to age minus years in the occupation minus six. ${ }^{12}$ We have a direct measure of experience: years in the occupation. We also know how many years the worker was at the same firm (tenure).

Information on the firm allows us to construct a number of firm-level indicators that reflect firm types of potential relevance for the gender gap. These variables are specific to the firm in which the individual worked, rather than to the individual. Some of them are straightforward firm characteristics, such as location and size, while others (e.g., share women and unionization) reflect workforce characteristics and group dynamics at the workplace level. Firm in big city indicates that a firm was located in one of the three largest towns: Stockholm, Gothenburg, or Malmö. Firm size

\footnotetext{
${ }^{9}$ Concern about economic and social issues, including gender issues, led to data collection via surveys and censuses in the United States and Europe from around 1880. As part of this movement, the Swedish Board of Commerce instigated large-scale statistical surveys of a number of industries, including printing, with statistician Henning Elmquist in charge.

${ }^{10}$ For details, see Burnette and Stanfors (2019).

${ }^{11}$ The hourly wage is expressed in ore, which is one hundredth of a Swedish krona. We primarily use the workers' own statements of hours worked and income for a normal working week.

${ }^{12}$ The average age of starting in the trade was 14.8 for men and 16.7 for women. This does not imply that women had, on average, two more years of schooling, but rather indicates different and gendered inroads to manufacturing industry.
} 
measures the total workforce of the firm (including workers who were not compositors).

We restrict our analysis to compositors for whom we have data on all variables of interest, excluding foremen. We also limit the data to firms hiring at least three compositors. Our sample consists of 2,551 individuals (2,216 men and 335 women) of which 1,084 (783 men and 301 women) worked in firms that had a gender-mixed set of compositors (i.e., at least one male and one female compositor). ${ }^{13}$ Compositors in the full sample worked for 234 different firms with workforces ranging from 4 to 581 , and 3 to 137 compositors. On average, each firm employed 68 workers and 11 compositors.

Table 2 shows averages by gender for the variables used in this study. Women earned less than men, were younger, and had less experience. The workforce was youthful, partly because the trade was expanding. Women were less likely to be married or have children than men, which was not always the case in manufacturing (Karlsson and Stanfors 2018). Men were more likely to have some secondary (including postprimary technical) education. Six years of schooling was compulsory for all Swedes, but secondary education was rare; 16 percent was well above the national average (Orring 1967). In line with extensive internal migration in Sweden at this time, a large share of workers were not born where they lived and worked. Women were less likely than men to be members of a union or a mutual aid society. Women were more likely to be apprentices (due to their relative youth), but men were more likely to work night shifts and Sundays, which affected their earnings positively. There is evidence of gender sorting across firms. Men were more likely to work in larger firms. Men worked in firms that were less feminized, while women, on average, had a larger share of female co-workers. These differences likely affected wages.

\section{UNDERSTANDING THE GENDER WAGE GAP AMONG COMPOSITORS}

On average, female compositors earned 71 percent as much per hour worked as did male compositors (Table 2). Among the apprenticed, who earned less while learning the trade, the raw wage gap was smaller, with female apprentices earning 96 percent as much as male apprentices. Among hand compositors, the wage gap was 26 percent, but among

\footnotetext{
${ }^{13}$ Both samples give essentially the same results, which indicates that the results are robust.
} 
TABLE 2

DESCRIPTIVE STATISTICS OF COMPOSITORS IN THE SWEDISH PRINTING INDUSTRY 1902/03: SHARES (IN PERCENT) AND MEANS OF VARIABLES USED IN ANALYSIS

\begin{tabular}{|c|c|c|c|c|c|c|}
\hline & \multicolumn{3}{|c|}{ Compositors in All Firms } & \multicolumn{3}{|c|}{ Compositors in Gender-Mixed Firms } \\
\hline & All & Men & Women & All & Men & Women \\
\hline Hourly earnings (ore) & $\begin{array}{c}36.6 \\
(19.9)\end{array}$ & $\begin{array}{c}38.1 \\
(20.2)\end{array}$ & $\begin{array}{c}27.1 \\
(13.9)\end{array}$ & $\begin{array}{c}34.9 \\
(17.6)\end{array}$ & $\begin{array}{c}37.5 \\
(18.2)\end{array}$ & $\begin{array}{c}28.2 \\
(13.7)\end{array}$ \\
\hline Hourly earnings hand compositors & $\begin{array}{c}34.2 \\
(17.7)\end{array}$ & $\begin{array}{c}35.5 \\
(18.0)\end{array}$ & $\begin{array}{c}26.4 \\
(13.2)\end{array}$ & $\begin{array}{l}33.6 \\
(16.6)\end{array}$ & $\begin{array}{c}36.0 \\
(17.3)\end{array}$ & $\begin{array}{l}27.5 \\
(13.0)\end{array}$ \\
\hline Hourly earnings machine compositors & $\begin{array}{c}67.5 \\
(20.1)\end{array}$ & $\begin{array}{c}68.0 \\
(20.3)\end{array}$ & $\begin{array}{c}55.4 \\
(12.8)\end{array}$ & $\begin{array}{c}57.9 \\
(18.1)\end{array}$ & $\begin{array}{c}58.3 \\
(18.9)\end{array}$ & $\begin{array}{c}55.4 \\
(12.8)\end{array}$ \\
\hline Hourly earnings if apprentice & $\begin{array}{l}14.1 \\
(6.6)\end{array}$ & $\begin{array}{l}14.2 \\
(6.6)\end{array}$ & $\begin{array}{l}13.6 \\
(6.6)\end{array}$ & $\begin{array}{l}13.9 \\
(6.3)\end{array}$ & $\begin{array}{l}13.6 \\
(6.0)\end{array}$ & $\begin{array}{l}14.4 \\
(6.8)\end{array}$ \\
\hline Woman & 13.1 & - & - & 27.8 & - & - \\
\hline Age (years) & $\begin{array}{c}28.8 \\
(11.5)\end{array}$ & $\begin{array}{c}29.1 \\
(11.7)\end{array}$ & $\begin{array}{l}27.1 \\
(9.8)\end{array}$ & $\begin{array}{l}29.0 \\
(11.4)\end{array}$ & $\begin{array}{c}29.6 \\
(12.0)\end{array}$ & $\begin{array}{l}27.5 \\
(9.8)\end{array}$ \\
\hline Age of starting work in industry & $\begin{array}{l}15.0 \\
(3.5)\end{array}$ & $\begin{array}{l}14.8 \\
(3.4)\end{array}$ & $\begin{array}{l}16.7 \\
(3.4)\end{array}$ & $\begin{array}{l}15.5 \\
(4.1)\end{array}$ & $\begin{array}{l}15.0 \\
(4.2)\end{array}$ & $\begin{array}{l}16.6 \\
(3.4)\end{array}$ \\
\hline Experience (years) & $\begin{array}{c}13.8 \\
(11.3)\end{array}$ & $\begin{array}{c}14.4 \\
(11.5)\end{array}$ & $\begin{array}{l}10.4 \\
(9.5)\end{array}$ & $\begin{array}{l}13.6 \\
(11.2)\end{array}$ & $\begin{array}{c}14.6 \\
(11.6)\end{array}$ & $\begin{array}{l}10.9 \\
(9.5)\end{array}$ \\
\hline Tenure (years) & $\begin{array}{c}7.1 \\
(8.1)\end{array}$ & $\begin{array}{c}7.2 \\
(8.2)\end{array}$ & $\begin{array}{c}6.0 \\
(7.0)\end{array}$ & $\begin{array}{c}6.4 \\
(7.6)\end{array}$ & $\begin{array}{c}6.4 \\
(7.8)\end{array}$ & $\begin{array}{c}6.2 \\
(7.1)\end{array}$ \\
\hline Married & 34.7 & 38.7 & 8.1 & 28.2 & 35.9 & 8.3 \\
\hline Previously married & 1.1 & 1.1 & 1.5 & 1.4 & 1.3 & 1.7 \\
\hline Children at home & 27.4 & 30.6 & 6.6 & 22.7 & 28.9 & 6.6 \\
\hline Any secondary education & 14.7 & 16.2 & 4.5 & 16.1 & 20.6 & 4.7 \\
\hline Migrant & 51.2 & 52.4 & 42.7 & 53.8 & 57.7 & 43.5 \\
\hline Union member & 82.0 & 85.8 & 57.0 & 78.9 & 85.2 & 62.5 \\
\hline $\begin{array}{l}\text { Member of sickness } \\
\text { insurance fund }\end{array}$ & 71.6 & 72.2 & 67.5 & 75.0 & 76.2 & 71.8 \\
\hline Machine compositor & 7.2 & 7.9 & 2.4 & 5.4 & 6.5 & 2.7 \\
\hline Apprentice & 24.5 & 23.2 & 32.5 & 23.3 & 20.7 & 30.2 \\
\hline Night work & 4.4 & 4.9 & 1.5 & 2.6 & 2.9 & 1.7 \\
\hline Sunday work & 3.1 & 3.5 & 0.6 & 2.5 & 3.2 & 0.7 \\
\hline Firm size (number of workers) & $\begin{array}{c}68.2 \\
(111.3)\end{array}$ & $\begin{array}{c}71.3 \\
(115.5)\end{array}$ & $\begin{array}{c}48.0 \\
(74.7)\end{array}$ & $\begin{array}{c}118.4 \\
(154.1)\end{array}$ & $\begin{array}{c}144.0 \\
(167.9)\end{array}$ & $\begin{array}{c}51.6 \\
(77.9)\end{array}$ \\
\hline Firm in big city & 46.6 & 46.2 & 49.6 & 57.9 & 60.3 & 51.8 \\
\hline Share women in workforce & $\begin{array}{c}0.15 \\
(0.19)\end{array}$ & $\begin{array}{c}0.10 \\
(0.13)\end{array}$ & $\begin{array}{c}0.44 \\
(0.24)\end{array}$ & $\begin{array}{c}0.27 \\
(0.18)\end{array}$ & $\begin{array}{c}0.22 \\
(0.13)\end{array}$ & $\begin{array}{c}0.41 \\
(0.24)\end{array}$ \\
\hline Union density & $\begin{array}{c}0.67 \\
(0.22)\end{array}$ & $\begin{array}{c}0.69 \\
(0.19)\end{array}$ & $\begin{array}{c}0.53 \\
(0.31)\end{array}$ & $\begin{array}{c}0.62 \\
(0.23)\end{array}$ & $\begin{array}{c}0.64 \\
(0.20)\end{array}$ & $\begin{array}{c}0.58 \\
(0.28)\end{array}$ \\
\hline Number of compositors & 2,551 & 2,216 & 335 & 1,084 & 783 & 301 \\
\hline Number of firms & 234 & 228 & 84 & 78 & 78 & 78 \\
\hline
\end{tabular}

Note: Standard deviations in parentheses.

Source: See Table 1. 


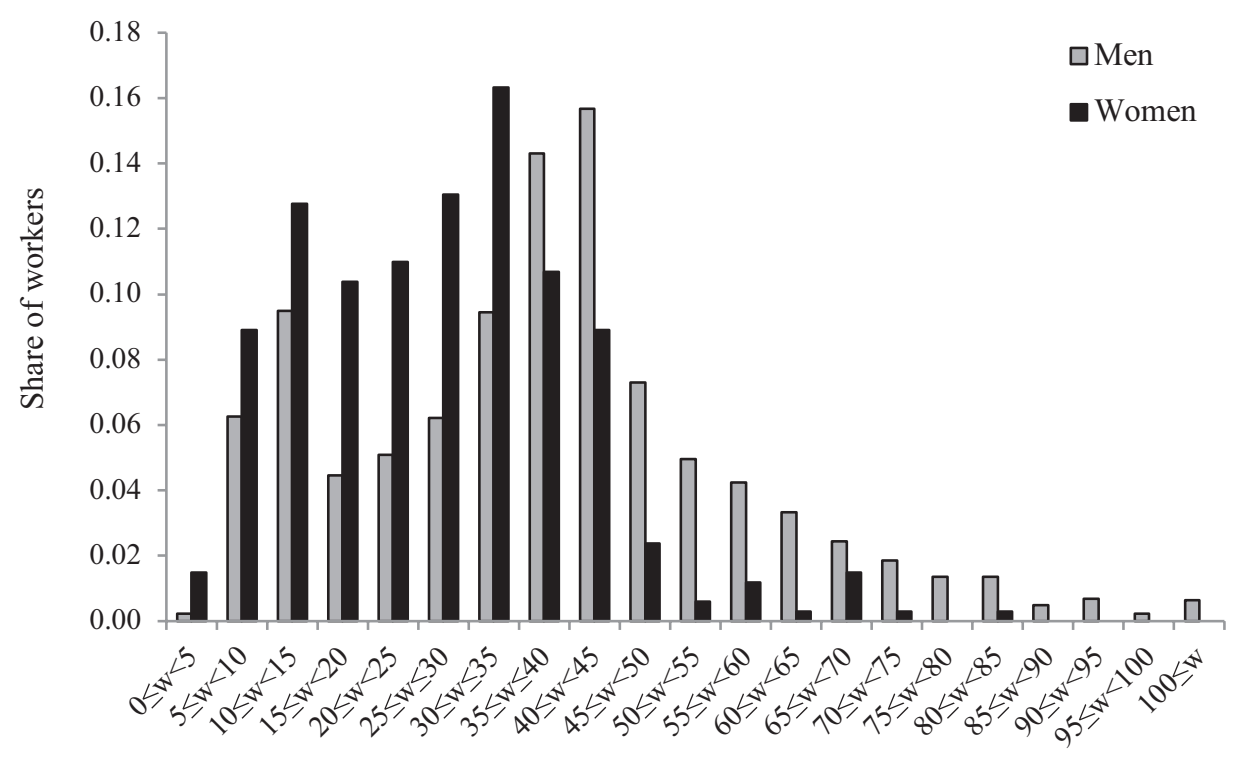

FIGURE 1

WAGE DISTRIBUTIONS BY SEX

Source: See Table 1.

machine compositors, handling the new technology, the gap was only 19 percent. Women were, however, less likely to work by machine. The gender wage gaps were consistently smaller in gender-mixed firms because the average wage for men was lower, while the average wage for women was higher. Among machine compositors in gender-mixed firms, the gender wage gap was only 5 percent.

The range of wages was wide for both men and women. Figure 1 shows the distribution of hourly wages by gender. Women were more likely to earn wages less than 35 ore per hour, but the wage distributions overlap. The female wage distribution was more compressed than the male wage distribution; we attribute this to both the smaller variation in characteristics among women and the fact that women had shorter apprenticeships and less training than men did.

\section{Empirical Framework}

Our goal is to explain the gender wage gap among compositors using individual and firm characteristics, thereby demonstrating that access to better data erodes the otherwise unexplained portion of the wage gap. 
We start by estimating ordinary least squares (OLS) wage models where the natural logarithm of gross hourly wage is modeled as a function of individual characteristics expected to be correlated with productivity, including gender. We explore the impact of firm characteristics proven important for wages. We add firm fixed effects, as we are interested in an unbiased estimation of individual-specific variables and to control for unobserved heterogeneity across firms, which may arise from the recruitment of different kinds of labor. There may also be unobserved management practices, including hiring, firing, and training across firms, affecting men's and women's earnings. We decompose the impacts of covariates, quantifying how much of the gender wage gap is explained by individual and firm characteristics using the method developed by Gelbach (2016). Gelbach recommends against using stepwise addition of covariates to a regression model, as the interpretation is sensitive to the order variables enter the model. Instead, he proposes a decomposition method based on the formula for calculating omitted variable bias, which avoids such problems. ${ }^{14}$

The Gelbach decomposition starts with a "restricted" wage regression, with one set of covariates, and then adds another regression including all relevant explanatory variables. The objective is to estimate the independent statistical impacts of the additional covariates. In our case, we start with a model only controlling for gender. We then add individual and job-related characteristics as well as firm covariates. We use alternative specifications with firm characteristics and firm fixed effects to measure the firm's impact on wages.

The model, using measured firm characteristics, is

$$
\ln W_{i}=\alpha_{0}+D \beta_{\mathrm{f}}+\mathbf{X}_{i} \beta_{\mathrm{x}}+\mathbf{Z}_{j} \beta_{\mathrm{z}}+u_{j}+\varepsilon_{i}
$$

where $\ln W_{i}$ is the natural $\log$ of the hourly wage for individual $i, D$ is the dummy variable indicating a female worker, $\mathbf{X}$ is a vector of individual human capital and job-related characteristics, $\mathbf{Z}$ is a vector of firm-related characteristics, $u$ is the firm-specific error term, and $\varepsilon$ is the individualspecific error term. In this model, the portion of the wage gap explained by individual characteristics is

$$
\left(\overline{\mathbf{X}}_{f}-\overline{\mathbf{X}}_{m}\right) \beta_{x}
$$

${ }^{14}$ Grove, Hussey, and Jetter (2011) find that the Gelbach decomposition provides similar results to a Blinder-Oaxaca decomposition using pooled coefficients, which Neumark (1988) suggested was a better measure of the no-discrimination wage structure than coefficients from regressions using one single gender. 
where $\overline{\mathbf{X}}_{m}$ is the vector of average individual characteristics for men and $\overline{\mathbf{X}}_{f}$ is the vector of averages for women. The portion of the wage gap explained by firm characteristics is

$$
\left(\overline{\mathbf{Z}}_{f}-\overline{\mathbf{Z}}_{m}\right) \beta_{x}
$$

The unexplained portion of the wage gap is $\beta_{f}$, the coefficient on the female dummy.

In the second model, we estimate firm fixed effects $\left(G_{j}\right)$. Due to collinearity, we cannot also include firm characteristics $(\mathbf{Z})$ in the following model:

$$
\ln W_{i}=\alpha_{0}+D \beta_{f}+\mathbf{X}_{i} \beta_{x}+G_{j}+\varepsilon_{i},
$$

Once fixed effects are added, the gender gap is estimated from withinfirm differences, so the full sample and the subset of firms that hired both male and female compositors give the same results. We explore differences across firms by estimating models for firms in the three biggest cities, and firms elsewhere.

The Gelbach decomposition allows us to explain the sources of the gender wage gap and determine what portion of the observed gap can be explained by individual and firm characteristics. Like other decomposition methods, such as the Oaxaca-Blinder, this is not a proper test for wage discrimination. The unexplained portion of the wage gap may overestimate or underestimate discrimination if unobserved characteristics are correlated with gender or if observed characteristics are themselves results of discrimination (e.g., in education and hiring).

A simple, competitive model of the labor market suggests that all firms should pay the same wage to workers of the same quality. There are, however, reasons why earnings would differ across firms. First, wage differences across firms might reflect sorting. If some firms are more likely to hire workers with better unmeasured characteristics, they will have to pay higher wages. Another explanation is amenities related either to location or to the work contract. Cities were more expensive to live in and often unhealthy environments, so workers may have required a higher wage to work in urban locations. According to this logic, firms with worse working conditions should also pay more. Thus, differences across firms do not necessarily represent differences in the welfare of workers; workers who earn more might not have higher utility because they must put up with workplace disamenities. Men and women, however, might get different utility from the working environment; overtime work 
might be a benefit to a man trying to maximize money income, but not to a woman with domestic responsibilities. A third explanation is that some firms have pricing power. In less urban locations, workers may have fewer alternatives, giving firms monopsony power. If men have better options, they may be less likely to accept low-wage jobs.

\section{RESULTS}

Table 3 shows results from OLS models estimating gender wage gaps for all firms and gender-mixed firms. The first column of each section shows the raw gender wage gap, which was 0.33 log points across all firms and $0.28 \log$ points in gender-mixed firms. The other columns ((2)(4)) present results from models including individual and job-related characteristics and either firm characteristics or firm fixed effects. Results are in line with the expectations from theory and previous research.

We use a quadratic spline as the functional form for experience because this captures the shape of the wage profile better than a simple quadratic. ${ }^{15}$ Wage-experience profiles for compositors were similar to other nineteenth-century wage profiles in that they are steep for a few years and then become quite flat (Hatton 1997; Burnette 2006; Stanfors and Burnette 2015). Wages rose rapidly for the first eight years of experience, after which the wage profile flattened out. ${ }^{16}$ The relationship between marriage and the wage was positive, which could be due to work effort or selection into marriage. The presence of children, however, did not have any additional significant relationship with the wage. Secondary education was not particularly important. Union members and members of sickness insurance funds both had higher earnings. ${ }^{17}$ There is evidence of compensating differentials; night and Sunday work were associated with higher earnings. Apprentices earned less, and machine compositors earned more, than compositors working by hand. Restricting the sample to gender-mixed firms does not change the results in any meaningful way. The sign of the coefficient on night work changes, but this seems

\footnotetext{
${ }^{15}$ The spline variable is $\max \{0$, age- $k\}$, where $k$ is the break point. We determine the break point by estimating functions with a wide range of $k$ 's and choosing the break point that gives the highest $R^{2}$. Stanfors and Burnette (2015) conclude that using a quadratic functional form leads to underestimation of the wage gap for workers in their twenties.

${ }^{16}$ Wages did not differ by gender for the first six years of experience. After that, the female wage profile flattened, while the male profile continued to rise for two more years, creating a gender gap for workers with more than six years of experience. Tenure, on average, mattered little for wages (Burnette and Stanfors 2018).

${ }^{17}$ While union members earned higher wages than non-members, those working at firms with a high unionization rate did not earn more. This is consistent with positive selection into unions, but not with a causal effect of unions on wages.
} 


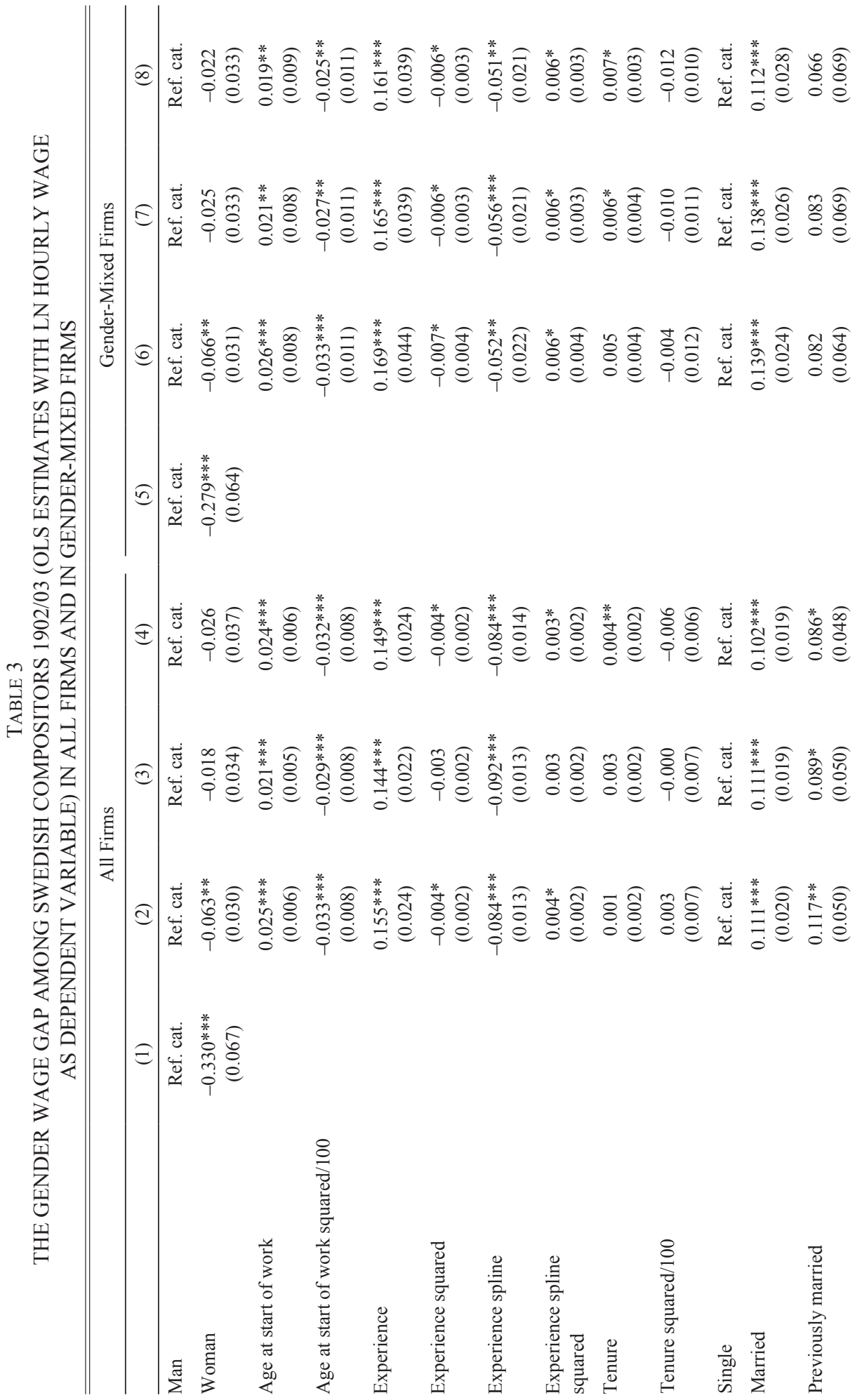




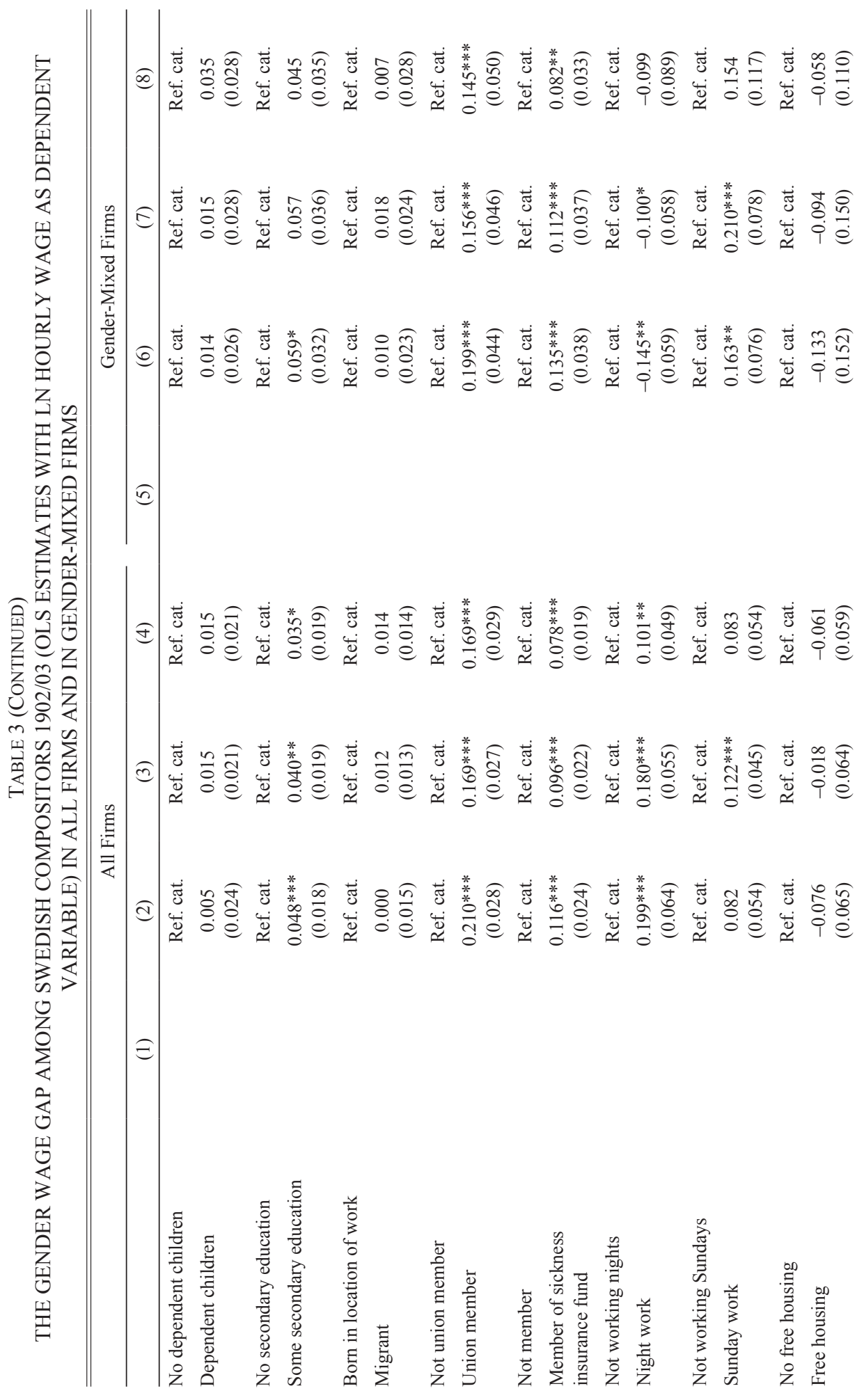




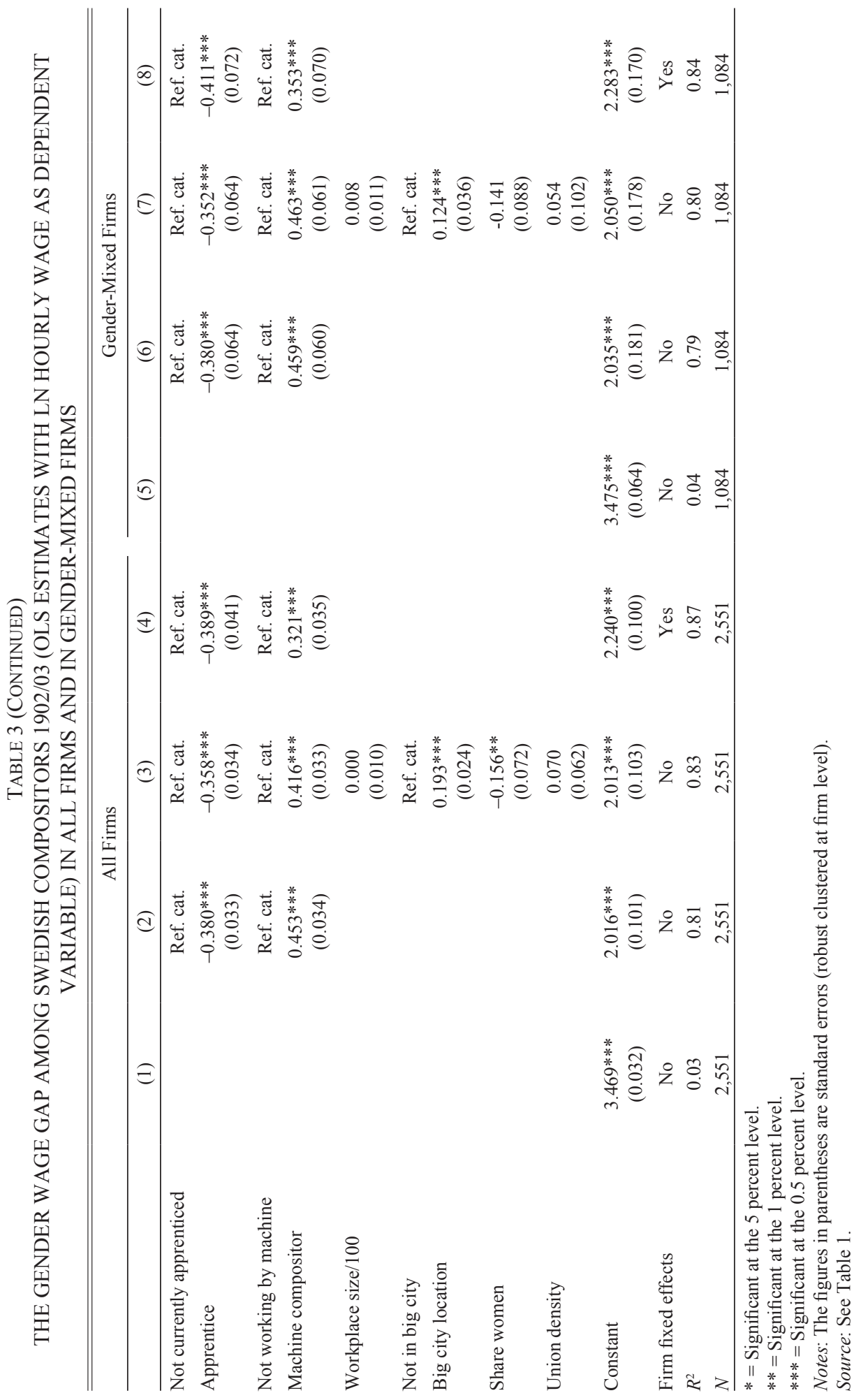


to be firm related; when firm fixed effects are included in the model, it is not significant.

Columns (3) and (4) indicate that the firm was important for the gender wage gap among compositors circa 1900. With the inclusion of firm characteristics, or firm fixed effects, the coefficient indicating the cost of being a woman becomes small and not statistically significant. This indicates that there was no discernable wage discrimination within firms. The results suggest that, by controlling for firm size, location, share of women in the workforce, and union density, we are able to capture most firm heterogeneity of relevance for gender wage differentials across firms. When all these characteristics are included, location and the share of women in the workforce are the only firm characteristics with statistically significant coefficients.

Workers in the three largest cities earned more, indicating a compensating differential for higher costs of living and other city disamenities. Firms with more female workers paid less, consistent with Ostroff and Atwater's (2003) hypothesis that work with women is devalued. An alternative explanation is that some firms paid lower wages and had trouble attracting men, who generally had better labor market alternatives than women did.

Table 4 displays results from decompositions of the gender wage gap among all and gender-mixed firms using the Gelbach method described above. These results allow us to say something about the individual and firm components of the gender wage gap among compositors at the turn of the last century. Among all firms, individual and job-related characteristics explain $0.255 \log$ points, which is the bulk ( 77 percent) of the raw wage gap. Firm characteristics explain a further $0.057 \mathrm{log}$ points, or 17 percent of the raw wage gap, leaving only a gap of 0.018 log points (5 percent) unexplained. Using firm fixed effects instead of measured firm characteristics gives us similar results, though the firm component is larger because we also capture unmeasurable firm factors; here, worker and job characteristics explain 72 percent of the gender wage gap and firm fixed effects explain 21 percent, leaving 8 percent of the gap unexplained. Among gender-mixed firms, the raw gender wage gap is smaller and individual characteristics vary less, but the firm and the unexplained components of the gender wage gap are approximately the same. If firm fixed effects are included, worker and job characteristics explain 69 percent of the raw gender wage gap, the firm explains 23 percent, and 8 percent remain unexplained.

Because the data include a wide range of individual and job-related characteristics, we are able to explain three-quarters of the wage gap 
TABLE 4

GELBACH DECOMPOSITION OF COVARIATES: THE GENDER WAGE GAP AMONG SWEDISH COMPOSITORS, IN ALL FIRMS AND IN GENDER-MIXED FIRMS

\begin{tabular}{|c|c|c|c|c|}
\hline & \multicolumn{2}{|c|}{ All } & \multicolumn{2}{|c|}{ Gender-Mixed } \\
\hline & (1) & (2) & (3) & (4) \\
\hline Age and experience & -0.089 & -0.080 & -0.058 & -0.054 \\
\hline Tenure & -0.004 & -0.003 & -0.000 & -0.000 \\
\hline Family status & -0.037 & -0.034 & -0.041 & -0.038 \\
\hline Education & -0.005 & -0.004 & -0.009 & -0.007 \\
\hline Migrant & -0.001 & -0.001 & -0.002 & -0.001 \\
\hline Union member & -0.049 & -0.050 & -0.035 & -0.033 \\
\hline $\begin{array}{l}\text { Member of sickness } \\
\text { insurance fund }\end{array}$ & -0.005 & -0.004 & -0.005 & -0.004 \\
\hline Apprentice & -0.033 & -0.036 & -0.034 & -0.039 \\
\hline Machine worker & -0.023 & -0.018 & -0.018 & -0.014 \\
\hline Other job characteristics ${ }^{\mathrm{a}}$ & -0.010 & -0.005 & -0.003 & -0.002 \\
\hline $\begin{array}{l}\text { Individual and job-related } \\
\text { characteristics }\end{array}$ & -0.255 & -0.236 & -0.206 & -0.192 \\
\hline Firm characteristics ${ }^{\mathrm{b}}$ & -0.057 & - & -0.047 & - \\
\hline Firm fixed effects & - & -0.068 & - & -0.063 \\
\hline Explained & -0.312 & -0.305 & -0.254 & -0.256 \\
\hline Unexplained & -0.018 & -0.025 & -0.025 & -0.023 \\
\hline $\begin{array}{l}\text { Total gender gap } \\
\text { (coefficient) }\end{array}$ & -0.330 & -0.330 & -0.279 & -0.279 \\
\hline
\end{tabular}

Notes: Column (1) presents Gelbach decomposition results for all firms including measurable firm characteristics, while Column (2) presents results including firm fixed effects. Columns (3) and (4) present similar decomposition results for the gender-mixed firms only. Column (3) includes firm characteristics, while Column (4) includes firm fixed effects.

${ }^{a}$ Other job characteristics include night work, Sunday work, and receipt of free housing.

${ }^{\mathrm{b}}$ Firm characteristics include size, location, share women in workforce, and union density.

Source: See Table 1.

by these characteristics alone. Had we not had information on the firm, we might have concluded that a large portion of the wage gap remained unexplained, indicating wage discrimination. Because we are able to match workers to the firms where they worked, and have firm characteristics, we are able to explain more than 90 percent of the gender wage gap across firms nationwide. Thus, there is little indication of withinfirm wage discrimination based on gender for Swedish compositors circa 1900.

We delve deeper into the individual and firm components of the gender wage gap, decomposing it by firm location, using the Gelbach method. Table 5 shows that firms in the three major cities (Stockholm, Gothenburg, and Malmö) feature a slightly smaller gender wage gap, and 
TABLE 5

DECOMPOSITION OF COVARIATES: THE GENDER WAGE GAP AMONG SWEDISH COMPOSITORS 1902/03 BY FIRM LOCATION, IN ALL FIRMS (A) AND GENDER-MIXED FIRMS (B)

\begin{tabular}{|c|c|c|c|c|}
\hline Panel A & \multicolumn{2}{|c|}{ Big City Location $^{c}$} & \multicolumn{2}{|c|}{ Other Location } \\
\hline Age and experience & -0.072 & -0.064 & -0.117 & -0.108 \\
\hline Tenure & -0.013 & -0.010 & 0.001 & 0.000 \\
\hline Family status & -0.046 & -0.043 & -0.028 & -0.027 \\
\hline Education & 0.000 & -0.003 & -0.006 & -0.005 \\
\hline Migrant & -0.003 & -0.004 & -0.000 & -0.000 \\
\hline Union member & -0.035 & -0.031 & -0.066 & -0.072 \\
\hline Member of sickness insurance fund & -0.001 & -0.001 & -0.010 & -0.008 \\
\hline Apprentice & -0.013 & -0.015 & -0.059 & -0.060 \\
\hline Machine worker & -0.028 & -0.023 & -0.018 & -0.014 \\
\hline Other job characteristics ${ }^{\mathrm{a}}$ & -0.016 & -0.008 & -0.006 & -0.005 \\
\hline Individual and job-related characteristics & -0.226 & -0.202 & -0.308 & -0.298 \\
\hline Firm characteristics ${ }^{\mathrm{b}}$ & -0.088 & - & -0.024 & - \\
\hline Firm fixed effects & - & -0.145 & - & -0.018 \\
\hline Explained & -0.314 & -0.346 & -0.333 & -0.316 \\
\hline Unexplained & -0.020 & 0.012 & -0.023 & -0.040 \\
\hline Total gender gap (coefficient) & -0.334 & -0.334 & -0.356 & -0.356 \\
\hline \multicolumn{5}{|l|}{ Panel B } \\
\hline Age and experience & -0.050 & -0.049 & -0.041 & -0.040 \\
\hline Tenure & -0.006 & -0.005 & -0.002 & 0.000 \\
\hline Family status & -0.046 & -0.045 & -0.026 & -0.028 \\
\hline Education & -0.002 & -0.003 & -0.016 & -0.010 \\
\hline Migrant & -0.010 & -0.010 & 0.001 & 0.003 \\
\hline Union member & -0.029 & -0.023 & -0.038 & -0.046 \\
\hline $\begin{array}{l}\text { Member of sickness } \\
\text { insurance fund }\end{array}$ & -0.001 & -0.001 & -0.006 & -0.003 \\
\hline Apprentice & -0.015 & -0.017 & -0.040 & -0.049 \\
\hline Machine worker & -0.008 & -0.006 & -0.025 & -0.021 \\
\hline Other job characteristics ${ }^{\mathrm{a}}$ & -0.001 & -0.001 & -0.009 & -0.003 \\
\hline Individual and job-related characteristics & -0.168 & -0.160 & -0.202 & -0.197 \\
\hline Firm characteristics $^{\mathrm{b}}$ & -0.049 & - & -0.003 & - \\
\hline Firm fixed effects & - & -0.087 & - & 0.001 \\
\hline Explained & -0.217 & -0.247 & -0.205 & -0.196 \\
\hline Unexplained & -0.021 & 0.009 & -0.049 & -0.058 \\
\hline Total gender gap (coefficient) & -0.238 & -0.238 & -0.254 & -0.254 \\
\hline
\end{tabular}

Notes: ${ }^{\text {a }}$ Other job characteristics include night work, Sunday work, and receipt of free housing. ${ }^{\mathrm{b}}$ Firm characteristics include size, share women in workforce, and union density. ${ }^{\mathrm{c}}$ Big city location is in one of the three major cities (Stockholm, Gothenburg, and Malmö).

Source: See Table 1. 
firm characteristics (both measured and unobserved) explain a large part of it. Among all big city firms (Panel A), we are able to explain much of the gender wage gap (and even more than the full gap when including firm fixed effects ${ }^{18}$ ). Among firms outside of the three big cities, individual characteristics explain a larger fraction, and firm characteristics a much smaller fraction, of the wage gap. Limiting the data to gendermixed firms (Panel B) gives the same results for firms in big cities, but among gender-mixed firms located outside of the three big cities, two things stand out: that the firm explains none of the gender wage gap and that a much larger component of the gap - about 20 percent - is left unexplained.

Our results suggest that, in general, differences across firms were an important part of explaining the gender wage gap for compositors. We can only speculate about the roots of these differences. One potential explanation is sorting of workers on unobservable characteristics; if some firms hired workers with better unmeasured characteristics, they would have had to pay higher wages. Table 6 demonstrates that there was sorting across firms by measured characteristics, to the advantage of big city and large firms, so it is not unreasonable to expect that there would also have been sorting by unmeasured characteristics. ${ }^{19}$ Our results are also consistent with compensating differentials; firms located in the three largest cities paid more, likely as compensation for a high cost of living. Higher wages in cities could also be explained by differences in firm pricing power; firms outside of the big cities could pay less because workers had fewer alternatives that paid well, particularly for women. Higher wages in big city and large firms could also be the result of higher unionization and more union power.

Firms might also differ in how they arrange the work contract. Goldin (1986) suggests that nineteenth-century firms used either piece rates or delayed compensation to motivate workers. The compositors that we study were generally paid time-rate wages, so firms may have used delayed compensation. In regressions including only individual characteristics (Table 3, Column (2)), tenure is not significant and the point estimates suggest that 10 years of tenure are associated with only 1.3 percent higher wages. However, when adding firm fixed effects to the model, tenure becomes significant and the point estimates suggest that

\footnotetext{
${ }^{18}$ This means that, based on individual and firm characteristics, the wage gap should have been slightly larger than it actually was.

${ }^{19}$ When it comes to sorting of workers, gender-mixed firms, of course, have higher shares of female workers. Otherwise, sorting is similar across all and gender-mixed firms with the notable exception of union density, which was substantially lower in firms outside of big cities.
} 
TABLE 6

SORTING OF COMPOSITORS WITH RESPECT TO CERTAIN CHARACTERISTICS (SHARES AND MEANS) ACROSS FIRMS BY LOCATION AND FIRM SIZE, ALL FIRMS (A) AND GENDER-MIXED FIRMS (B)

\begin{tabular}{lcccc}
\hline \hline & $\begin{array}{c}\text { Big City } \\
\text { Firms }\end{array}$ & $\begin{array}{c}\text { Firms outside } \\
\text { of Big Cities }\end{array}$ & Small Firms $^{\mathrm{a}}$ & Large Firms $^{\mathrm{a}}$ \\
\hline Panel A & & & & \\
\hline Share women in workforce (\%) & 14.0 & 12.4 & 14.1 & 11.3 \\
Experience (years) & 16.2 & 11.8 & 12.5 & 16.5 \\
Share married workers (\%) & 39.7 & 30.2 & 31.8 & 40.2 \\
Workers with any secondary education (\%) & 16.7 & 12.9 & 13.9 & 16.1 \\
Union density (\%) & 87.7 & 77.0 & 78.9 & 87.9 \\
Members of sickness insurance fund (\%) & 80.8 & 63.6 & 64.1 & 86.0 \\
\hline Panel B & & & & 20.1 \\
\hline Share women in workforce (\%) & 24.8 & 31.8 & 33.7 & 15.5 \\
Experience (years) & 15.4 & 11.0 & 12.0 & 34.5 \\
Share married workers (\%) & 32.2 & 22.8 & 23.4 & 17.8 \\
Workers with any secondary education (\%) & 16.7 & 15.4 & 14.9 & 84.5 \\
Union density (\%) & 86.5 & 68.4 & 74.5 & 84.5 \\
Members of sickness insurance fund (\%) & 82.3 & 64.9 & 67.6 & \\
\hline
\end{tabular}

Note: ${ }^{\text {a }}$ Small firms have less than 40 employees in total, while large firms have more than 40 employees. Source: See Table 1.

10 years of tenure are associated with 3.4 percent higher wages. This indicates important differences between firms in whether tenure mattered for wages.

Firms in the three major cities rewarded tenure, but firms elsewhere did not. Table 7 presents both the estimated wage benefit of an additional ten years of tenure (holding experience constant) and $p$-values for significance tests. In the first specification (no interactions), we do not permit the impact of tenure to differ by gender and the $p$-value measures the significance of excluding the tenure and tenure-squared terms. In the second specification (with interactions), we interact the gender dummy with all of the experience and tenure terms, allowing returns to both experience and tenure to vary by gender. We test whether all tenure variables are jointly significant and whether the interactions between the gender dummy and the tenure variables are significant.

The results consistently suggest that tenure was not significant for wages at firms outside of the largest cities. All the point estimates suggest negative returns to tenure, but none are significant. At big city firms, however, returns to tenure were substantial and statistically significant. In the first specification, ten years of tenure were associated with a $0.09 \log$ 
TABLE 7

RETURN TO TENURE FOR COMPOSITORS BY FIRM LOCATION, ALL FIRMS (A) AND GENDER-MIXED FIRMS (B)

\begin{tabular}{|c|c|c|c|}
\hline & $\begin{array}{c}\text { All } \\
\text { Firms }\end{array}$ & $\begin{array}{l}\text { Big City } \\
\text { Firms }\end{array}$ & $\begin{array}{c}\text { Firms outside } \\
\text { of Big Cities }\end{array}$ \\
\hline \multicolumn{4}{|l|}{ Panel A } \\
\hline \multicolumn{4}{|l|}{ No interactions } \\
\hline Return to ten years of tenure (log points) & 0.03 & 0.09 & -0.03 \\
\hline$p$-value ${ }^{\mathrm{a}}$ & 0.010 & 0.000 & 0.305 \\
\hline \multicolumn{4}{|l|}{ With interactions } \\
\hline Return to ten years of tenure, men (log points) & 0.03 & 0.08 & -0.03 \\
\hline Return to ten years of tenure, women (log points) & 0.09 & 0.16 & -0.06 \\
\hline$p$-value tenure ${ }^{\mathrm{b}}$ & 0.004 & 0.000 & 0.640 \\
\hline$p$-value returns different by gender ${ }^{c}$ & 0.054 & 0.108 & 0.652 \\
\hline \multicolumn{4}{|l|}{ Panel B } \\
\hline \multicolumn{4}{|l|}{ No interactions } \\
\hline Return to ten years of tenure (log points) & 0.05 & 0.11 & -0.05 \\
\hline$p$-value ${ }^{a}$ & 0.058 & 0.000 & 0.546 \\
\hline \multicolumn{4}{|l|}{ With interactions } \\
\hline Return to ten years of tenure, men (log points) & 0.05 & 0.11 & -0.03 \\
\hline Return to ten years of tenure, women (log points) & 0.09 & 0.16 & -0.04 \\
\hline$p$-value tenure ${ }^{\mathrm{b}}$ & 0.034 & 0.000 & 0.814 \\
\hline$p$-value returns different by gender ${ }^{c}$ & 0.189 & 0.252 & 0.685 \\
\hline
\end{tabular}

Notes: ${ }^{\mathrm{a}} p$-value of an $F$-test of tenure and tenure squared. ${ }^{\mathrm{b}} p$-value of an $F$-test of tenure, tenure squared, woman $\times$ tenure, and woman $\times$ tenure squared. ${ }^{c} p$-value of an $F$-test of woman $\times$ tenure, and woman $\times$ tenure squared.

points increase in hourly earnings. The return to tenure was not limited to men (the gender difference in returns was not statistically significant at the 5 percent level), and the point estimates suggest that women received higher returns to tenure at big city firms. Such a pattern would be consistent with the hypothesis that women, due to their higher probability of leaving the firm, had to pay more of training costs and received a higher return (compare Lazear and Rosen 1990; Becker and Lindsay 1994). These results hold up for gender-mixed firms.

Thus, we have identified one way in which firms differed, with consequences for the gender wage gap. Firms in the three largest cities offered returns to tenure, while other firms did not. While we do not know why they did so, one possibility is that they were using delayed compensation to reduce monitoring costs and to reduce turnover in an urban setting where the best workers easily could find alternative employers. Returns to tenure were also in line with the union's strategy to protect the skills 
and wages among compositors. In addition, unionization was higher among big city firms than elsewhere, and this difference was particularly large among gender-mixed firms (Table 6, Panel B). While big city firms offered this compensation to both genders, it would have been less beneficial to women than to men because women, on average, had shorter tenures. Big city firms rewarded a characteristic that more men had, a form of differential treatment that affected their wages positively and added to the gender wage gap.

\section{CONCLUSION}

Based on a study of turn-of-the-last-century compositors working in the Swedish printing industry, we contribute to the understanding of the gender wage gap by reporting three central findings. First, using a rich employer-employee matched data set with national coverage of men and women holding the same job, we have been able to explain almost the entire gender wage gap among compositors. We thus extend the findings regarding limited wage discrimination around 1900 to a group of skilled manufacturing workers who were, at the time when our study is situated, considered labor aristocracy, earned wages well above the average (male) industrial workers, and thus may be considered to have jobs at the top of manufacturing. Typesetting was gender-mixed, though men dominated the trade. Strength was unimportant, but cognitive skills, such as being able to read and write reverse image, were part of the job. Typesetting was thus a brain rather than a brawn job and did not keep women out based on their physical traits. Compared to alternatives, typesetting was relatively more rewarding to women than to men because women's jobs generally paid less.

Second, we are able to say something about the foundations of the gender wage gap among compositors. There was a gender wage gap of 33 log points across all firms and 28 log points among gender-mixed firms. Around three-fourths of this gap is explained by a worker component consisting of individual and job-related characteristics. A further one-fifth of the gap is explained by a firm component, including both observable and unobservable characteristics, leaving only about 5 percent of the gender wage gap unexplained. This remaining gap is not statistically significant. The result is in line with studies that, by exploiting modern, yet similar, data sets, establish that men and women working in the same occupation for the same employer receive the same pay (Meyersson Milgrom, Petersen, and Snartland 2001). Hence, within-job wage discrimination is often not a driving force for the gender wage gap. Rather, alternative 
forms of discrimination are at play together with gender sorting across occupations and firms in the past as well as in the present day.

Third, we find important differences across firms, particularly with respect to location, with the firm component explaining more of the gender wage gap among compositors across firms in the three major cities (Stockholm, Gothenburg, and Malmö) than elsewhere. These firms were, to some extent, different in observable characteristics, but also, it seems, with respect to unobservables, including workplace organization and practices. That location mattered is particularly true for gender-mixed firms, for which there is a relatively large unexplained component of the gender wage gap among firms outside of the big cities. This suggests that, when possible, at least firm location should be included in studies of the gender wage gap.

Our results caution against interpreting the unexplained wage gap as a measure of discrimination. A data set with fewer individual characteristics, or without information on firm characteristics, would have found a significant unexplained wage gap even within this one occupational group. This suggests that some of the previously unexplained gender wage gaps for historical contexts are likely products of data lacking detailed information on workers, jobs, and firms rather than evidence of wage discrimination per se. This does not mean that women were always treated fairly, of course. We have studied only one occupation, and we cannot say that entry into that occupation or across firms was genderneutral, but the results are nevertheless important.

Most wage studies, particularly historical studies, have focused on worker characteristics (for which gender differences were large in the past) rather than firm characteristics. Previous studies, however, have demonstrated the importance of the firm for wages and the gender gap in current labor markets. Here, we have demonstrated that firms were just as important for wage setting in historical labor markets as they seem to be in present-day labor markets (Card, Cardoso, and Klein 2016; Sorkin 2017). Full understanding of the wage structure thus requires information on firms. Historical studies should ideally include information on the firm where individuals worked whenever possible. When that is not possible, they should at least consider the biases that may arise from the lack of such data. This will open the way for a new type of historical labor market study, adding a neglected dimension to group differences in labor market outcomes by addressing the role of the firm for workers' wages, careers, and well-being. Studies that can address firm differences, including the sorting of men and women across firms, will thus further our understanding of the gender wage gap. 


\section{REFERENCES}

Abbott, Edith. Women in Industry. New York: Appleton, 1910.

Abbott, Edith, and Sophonisba Breckinridge. "Employment of Women in Industries: Twelfth Census Statistics.” Journal of Political Economy 14, no. 1 (1906): 14-40. Abowd, John, Francis Kramarz, and David Margolis. "High Wage Workers and High Wage Firms." Econometrica 67, no. 2 (1999): 251-333.

Altonji, Joseph, and Rebecca Blank. "Race and Gender in the Labor Market." In Handbook of Labor Economics vol. 3, edited by Orly Ashenfelder and David Card, 3143-259. Amsterdam: North Holland, 1999.

Becker, Gary. The Economics of Discrimination. Chicago, IL: The University of Chicago Press, [1957] 1971.

- Human Capital. Chicago, IL: The University of Chicago Press, 1964.

Becker, Elizabeth, and Cotton Lindsay. "Sex Differences in Tenure Profiles: Effects of Shared Firm-Specific Investment.” Journal of Labor Economics 12, no. 1 (1994): 98-118.

Bertrand, Marianne. "The Glass Ceiling." Economica 85, no. 338 (2018): 205-31.

Bradby, Barbara, and Anne Black. "Women Compositors and the Factory Acts." Economic Journal 9, no. 34 (1899): 261-66.

Brown, Charles, and James Medoff. "The Employer Size Wage Effect." Journal of Political Economy 97, no. 5 (1989): 1029-57.

Burnette, Joyce. "How Skilled Were Agricultural Labourers in the Early Nineteenth Century?" Economic History Review 59, no. 4 (2006): 688-716.

- Gender, Work and Wages in Industrial Revolution Britain. Cambridge: Cambridge University Press, 2008.

_. "The Paradox of Progress: The Emergence of Wage Discrimination." European Review of Economic History 19, no. 2 (2015): 128-48.

Burnette, Joyce, and Maria Stanfors. "Understanding the Gender Gap among Turnof-the Century Swedish Compositors.” IFAU Working Paper 2018:1. Uppsala: Institute for Evaluation of Labour Market and Education Policy.

Burnette, Joyce, and Stanfors, Maria. "Replication: Understanding Gender Gap Further." Ann Arbor, MI: Inter-university Consortium for Political and Social Research [distributor], 2019-08-25. https://doi.org/10.3886/E111565V1.

Card, David, Ana Rute Cardoso, and Patrick Kline. "Bargaining, Sorting and the Gender Wage Gap: Quantifying the Impact of Firms on the Relative Pay of Women." Quarterly Journal of Economics 131, no. 2 (2016): 633-86.

Card, David, Joerg Heining, and Patrick Kline. "Workplace Heterogeneity and the Rise of West German Wage Inequality." Quarterly Journal of Economics 128, no. 3 (2013): 967-1015.

Carrington, William, and Kenneth Troske. "Gender Segregation in Small Firms." Journal of Human Resources 30, no. 3 (1998): 503-33.

Census Bureau. Occupations at the Twelfth Census. Washington, DC: Government Printing Office, 1904.

Chevalier, Arnaud. "Education, Occupation and Career Expectations: Determinants of the Gender Pay Gap for UK Graduates." Oxford Bulletin of Economics and Statistics 69, no. 6 (2007): 819-42.

Cox, Donald, and John Nye. "Male-Female Wage Discrimination in Nineteenth-Century France.” Journal of Economic History 49, no. 4 (1989): 903-20. 
Eden, Frederick. The State of the Poor. London: Davis, 1797.

Edgeworth, Francis. "Preface." In Women in the Printing Trades: A Sociological Study, edited by Ramsey MacDonald, v-xii. London: P. S. King \& Son, 1904.

Elmquist, Henning. Undersökning af tryckerier och därmed förenad handtering $i$ Sverige [Investigation of the Printing Industry in Sweden]. Stockholm: Kommerskollegium, 1909.

Friedman, Gerald. "Labor Unions in the United States," 2008. http://eh.net/encyclopedia/ labor-unions-in-the-united-states.

Gelbach, Jonah. "When Do Covariates Matter? And Which Ones, and How Much?" Journal of Labor Economics 34, no. 2 (2016): 509-43.

Goldin, Claudia. "Monitoring Costs and Occupational Segregation by Sex: A Historical Analysis." Journal of Labor Economics 4, no. 1 (1986): 1-27.

- Understanding the Gender Gap. New York: Oxford University Press, 1990.

"A Grand Gender Convergence: Its Last Chapter." American Economic Review 104, no. 4 (2014): 1091-119.

Grove, Wayne, Andrew Hussey, and Michael Jetter. "The Gender Pay Gap Beyond Human Capital: Heterogeneity in Noncognitive Skills and in Labor Market Tastes." Journal of Human Resources 46, no. 4 (2011): 827-74.

Haegeland, Torbjorn, and Tor Jakob Klette. "Do Higher Wages Reflect Higher Productivity? Education, Gender and Experience Premiums in a Matched PlantWorker Data Set." In The Creation and Analysis of Employer-Employee Matched Data, edited by John Haltwinger, Julia I. Lane, James R. Speltzer, Jules Theeuwes, and Kenneth Troske, 231-59. Amsterdam: Elsevier, 1999.

Hatton, Timothy. "The Immigration Assimilation Puzzle in Late Nineteenth-Century America." Journal of Economic History 57, no. 1 (1997): 34-62.

Heinze, Anja, and Elke Wolf. "The Intra-Firm Gender Wage Gap: A New View on Wage Differentials in Linked Employer-Employee Data." Journal of Population Economics 23, no. 3 (2010): 851-79.

Hellerstein, Judith, and David Neumark. "Sex, Wages and Productivity: An Empirical Analysis of Israeli Firm-Level Data." International Economic Review 40, no. 1 (1999): 95-123.

Hellerstein, Judith, David Neumark, and Kenneth Troske. "Wages, Productivity, and Worker Characteristics: Evidence from Plant-Level Production Functions and Wage Equations.” Journal of Labor Economics 17, no. 3 (1999): 409-46.

Karlsson, Tobias, and Maria Stanfors. "Risk Preference and Gender Differences in Union Membership in late Nineteenth-Century Manufacturing." Feminist Economics 24, no. 1 (2018): 114-41.

Kessler-Harris, Alice. Out to Work: A History of Wage-Earning Women in the United States. New York: Oxford University Press, 1982.

Kunze, Astrid. "The Gender Wage Gap in Developed Countries." In The Oxford Handbook of Women and the Economy, edited by Susan Averett, Laura Argys, and Saul Hoffman, 369-95. New York: Oxford University Press, 2018.

Lazear, Edward, and Sherwin Rosen. "Male-Female Wage Differentials in Job Ladders." Journal of Labor Economics 8, no. 1 (1990): S106-23.

Leonard, Jonathan. "Antidiscrimination or Reverse Discrimination: The Impact of Changing Demographics, Title VII, and Affirmative Action on Productivity." Journal of Human Resources 19, no. 2 (1984): 145-74. 
McHugh, Cathy. Mill Family: The Labor System in the Southern Cotton Textile Industry, 1880-1915. New York: Oxford University Press, 1988.

Mellow, Wesley. "Employer Size and Wages." Review of Economics and Statistics 64, no. 3 (1982): 495-501.

Meyersson Milgrom, Eva, Trond Petersen, and Vemund Snartland. "Equal Pay for Equal Work? Evidence from Sweden and a Comparison with Norway and the U.S." Scandinavian Journal of Economics 103, no. 4 (2001): 559-83.

Mincer, Jacob. Schooling, Experience, and Earnings. New York: Columbia University Press, 1974.

Moore, Henry. Laws of Wages. New York: Macmillan, 1911.

Neumark, David. "Employers' Discriminatory Behavior and the Estimation of Wage Discrimination." Journal of Human Resources 23, no. 3 (1988): 279-95.

Oi, Walter, and Todd Idson. "Firm-Size and Wages." In Handbook of Labor Economics vol. 3, edited by Orly Ashenfelter and David Card, 2165-214. Amsterdam: North Holland, 1999.

Orring, Jonas. Skolan i Sverige [The School System in Sweden]. Stockholm: Seelig, 1967.

Ostroff, Cheri, and Leanne Atwater. "Does Whom You Work with Matter? Effects of Referent Group Gender and Age Composition on Managers' Compensation." Journal of Applied Psychology 88, no. 4 (2003): 725-40.

Samuel, Raphael. "Mechanization and Hand Labour in Industrializing Britain." In The Industrial Revolution and Work in Nineteenth-Century Europe, edited by Lenard R. Berlanstein, 26-43. London: Routledge, 1992.

Schmick, Ethan. "Collective Action and Origins of the American Labor Movement." Journal of Economic History 78, no. 3 (2018): 744-84.

Slichter, Sumner. "Notes on the Structure of Wages." Review of Economics and Statistics 32, no. 1 (1950): 80-91.

Sorkin, Isaac. "The Role of Firms in Gender Earnings Inequality: Evidence from the United States." American Economic Review: Papers and Proceedings 107, no. 5 (2017): 384-87.

Stanfors Maria, and Joyce Burnette. "Estimating Historical Wage Profiles." Historical Methods: A Journal of Quantitative and Interdisciplinary History 48, no. 1 (2015): $35-51$.

Stanfors, Maria, Leunig, Tim, Eriksson, Björn, and Karlsson, Tobias. "Gender, Productivity and the Nature of Work and Pay: Evidence from the Late NineteenthCentury Tobacco Industry." Economic History Review 67, no. 1 (2014): 48-65.

Webb, Sidney. "The Alleged Differences in the Wages Paid to Men and Women for Similar Work." Economic Journal 1, no. 4 (1891): 635-62.

Wessel, Nils. Svenska typografförbundet 1887-1936: ett svenskt fackförbunds historia [The Swedish Typographers' Union 1887-1936: the History of a Trade Union]. Stockholm: Svenska typografförbundet, 1937.

\section{Archival Sources}

Undersökning av tryckerier mm 1903, Avdelningen för arbetsstatistik, HII a:1 vol 1-6 samt HII a:2 vol 1-12, Kommerskollegiets arkiv, National Archives (Riksarkivet), Stockholm. 